\title{
STUDENT FRATERNITY OF THE ART ACADEMY OF LATVIA "DZINTARZEME": LATVIAN NATIONAL ART CONSERVATION POLICY IN EXILE (1958-1987)
}

\begin{abstract}
Summary. After the proclamation of the Republic of Latvia in 1918, Latvia experienced a rapid influx of youth into its capital city of Riga, looking to obtain education in universities. Students began to build their academic lives and student societies. In 1923, students of the Art Academy of Latvia founded the "Dzintarzeme" ("Amberland") fraternity. The aim of "Dzintarzeme" was to unite nationally minded students of the Art Academy of Latvia and to promote the development of national art and self-education. Most "Dzintarzeme" members were faithful to the old masters and Latvian art. This phenomenon is significant, because "Dzintarzeme" members grew up with Latvian painting traditions, which are a remarkable heritage of interwar Latvia.

In 1940, when Latvia was occupied by the Soviet Union, "Dzintarzeme" was banned. A part of "Dzintarzeme" members were deported, killed in war, went missing, or stayed in the Latvian SSR; the remaining chose exile. Although scattered throughout the United States of America, Canada, and Australia, some members were able to rebuild and sustain the fraternity's life, gathering its members, organising trips and anniversary art exhibitions.

The aim of this research is to reflect on "Dzintarzeme's" activities in exile (1958-1987), focusing on the main factors of Latvian national art conservation policy: first, the ability of "Dzintarzeme's" ideology to preserve the values of Latvian national art in an international environment, and second, the problem of generational change and the enrollment of young Latvian artists who continued to maintain "Dzintarzeme" values in exile.
\end{abstract}

Keywords: student corporations, fraternity, Dzintarzeme, Art Academy of Latvia, exile, Latvian national art.

\section{INTRODUCTION}

Estonian, Latvian, and Lithuanian students' academic life has a long history and traditions dating back to the 19th century. The beginnings of the students' academic life are related to the University of Königsberg, University of Tartu, Vilnius University, and other universities in the Russian Empire, where Baltic students from the 19th century had a chance to obtain higher education. Student life outside studies was also rich with social and cultural events. Taking German student corporations, ${ }^{1}$ the origins of which can be traced back to the 14th century, but took present form in the 18th century at the German universities of Heidelberg, Jena, Göttingen, and later successfully spread throughout the German cultural space, as an example, Baltic students started forming their own student societies and, later, corporations. They were built on the German corporation traditions: ancient, strict regulations, academic fencing, and Latin terms. These corporations had patriotic motives behind them: winning respectable social positions for Estonians, Latvians, and Lithuanians, proving the equality of Baltic and German students, maintaining national identities of the Baltic states. Fraternity "Littuania", founded in 1820-1821 at the University of Königsberg, was probably the first German-style organisation related to Lithuania. ${ }^{2}$ Most of its members were students from Gumbinè and Klaipèda districts. In 1817, "Filomatai" was founded as the first Vilnius University student union: ${ }^{3}$ an organisation of self-education and moral development, and in 1820, "Filaretai", a student organisation also based at Vilnius University, was founded. ${ }^{4}$ Both organisations operated until 1823. The Estonian Students' Society, founded in $1870 \mathrm{in} \mathrm{Tartu,} \mathrm{is} \mathrm{the} \mathrm{oldest} \mathrm{academic} \mathrm{student} \mathrm{society}$ 
in Estonia, ${ }^{5}$ and in 1870 in Tartu, the first Latvian corporation "Lettonia" was founded. ${ }^{6}$

1919 was a meaningful year for Latvian students, when the University of Latvia, the Art Academy of Latvia, and the Riga Conservatory were founded. New Latvian students started looking for ways to organise their societies, including the students of the Art Academy of Latvia. In 1923, twelve students of the Art Academy of Latvia, in the narrow room of student Roberts Vitolins (1900-1974), founded the "Dzintarzeme" ("Amberland") fraternity. "Dzintarzeme" was the first academic student organisation of Latvian artists in Latvia and the first academic art students' organisation in the Baltics. As there were no similar academic art students' organisations in Latvia or the other Baltic states, the examples of organisational structure, everyday life, and academic fencing were taken from "Athenea", the student corporation of the Academy of Fine Arts Vienna. ${ }^{7}$

The aim of "Dzintarzeme" was to unite nationally minded students of the Art Academy of Latvia and to promote the development of national art and selfeducation. ${ }^{8}$ Its mottoes were "Brotherhood, greatness, joy" and "For beauty, a friend, and Amberland". Its colours were black, yellow, and blue. The black symbolised the gloomy everyday life, in which art shone like a bright star, the yellow represented the native cereal fields, and the blue stood for the ideals of art. These colours were used in the regalia, such as the ribbon ${ }^{9}$ and the student cap (Fig. 1). Their main everyday activities in the interwar period were literary evenings on the issues of Latvian art, academic fencing lessons, and closed and public art exhibitions. The latter provided the opportunity to improve their artistic abilities, popularise themselves, and sell paintings to fill the fraternity's cash box (Fig. 2).

Ideologically, most "Dzintarzeme" members were faithful to the old Latvian masters and Latvian art. Latvian national art dates back to the late 19th century, but its culmination was the interwar period. This loyalty is significant, because "Dzintarzeme" members grew up with the culmination of Latvian painting traditions, which are a remarkable heritage of interwar Latvia. Latvian art of the 1920s and the 1930s was characterised by national romanticism and retrospection. It can be explained as a construction of the historical self-confidence of the new country. There was an effort to idealise the life of Latvians, to promote public interest in Latvian mythology and etnography, and to show the beauty

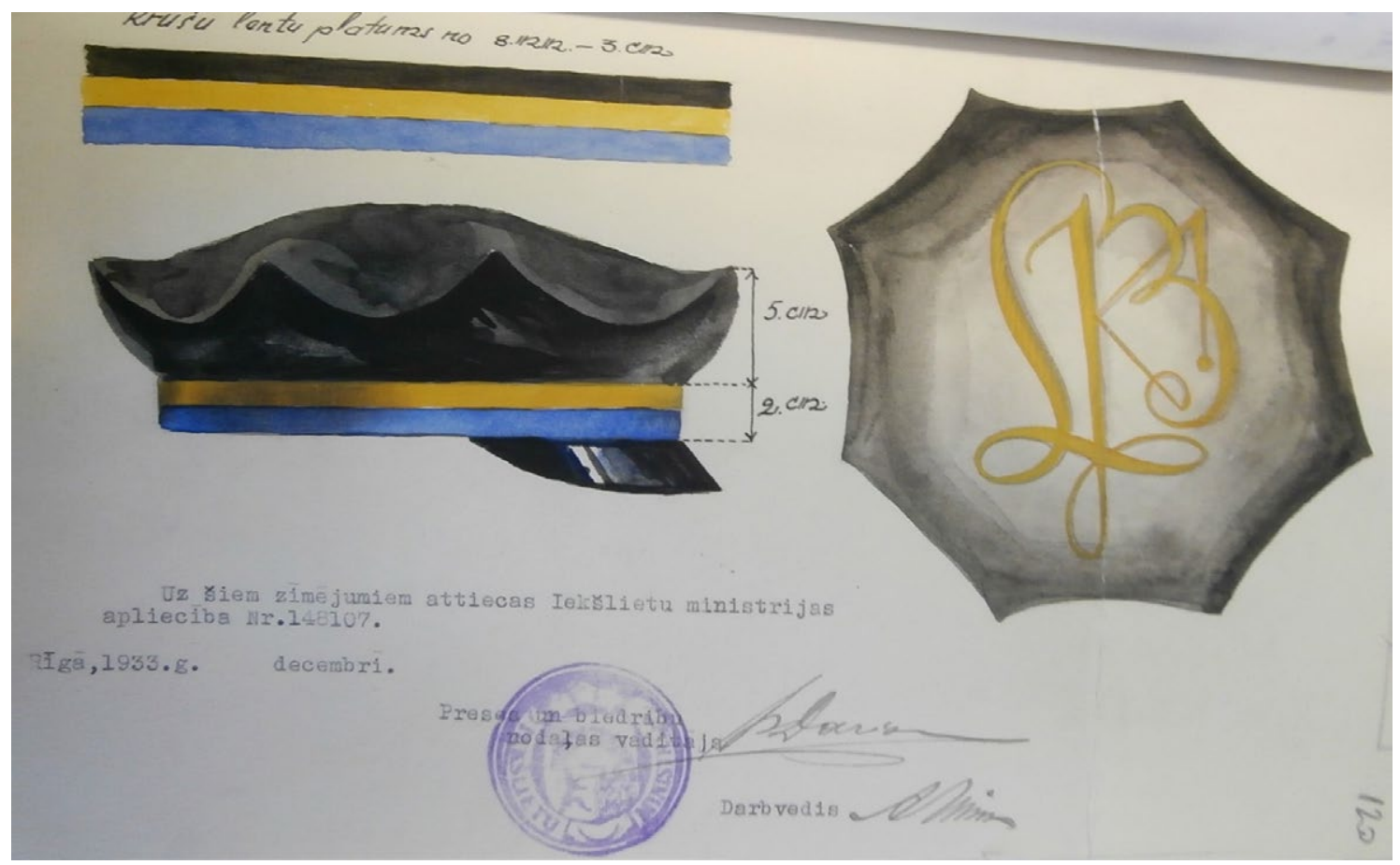

Fig. 1. "Dzintarzeme" regalia: the ribbon and the cap and a permission from the Ministry of the Interior to use them, 1933. LNA LVVA F. 2477, A.1, L.12, 120 


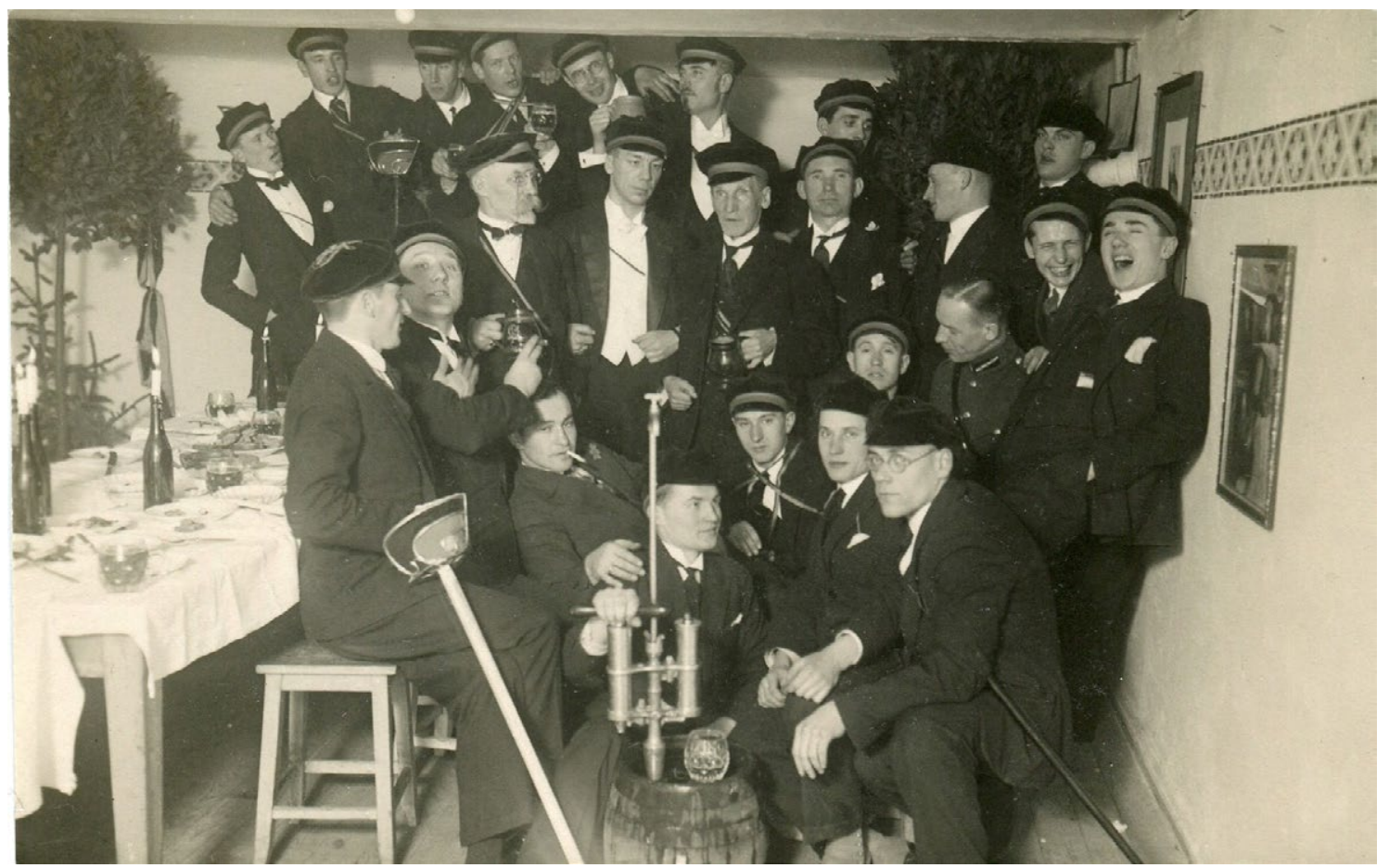

Fig. 2. "Dzintarzeme" members at an event, 1930s. CM 100964

of Latvian nature. "The Fathers" of the 1920s and the 1930s Latvian national art were painter Janis Roberts Tillbergs (1880-1972), graphic artist Jānis Zariņš (1869-1939), and painter Kārlis Miesnieks (1887-1977), who all denied modernism and were supporters of realism and national romanticism. ${ }^{10}$ All of them were professors at the Art Academy of Latvia and honorary members of "Dzintarzeme".

In 1940, when Latvia was occupied by the Soviet Union, "Dzintarzeme" was banned. A part of "Dzintarzeme" members were deported, killed in war, or went missing; the remaining continued to live in the Latvian SSR or chose exile. During the first post-war years, "Dzintarzeme" members who left Latvia were living in refugee camps in Germany or fled to Sweden by boats. In the late 1940s and the early 1950s, "Dzintarzeme" members were emigrating to the USA, Canada, and Australia (Fig. 3).

The aim of this research is to reflect on "Dzintarzeme's" activities in exile (1958-1987), focusing on the main factors of Latvian national art conservation policy: first, the ability of "Dzintarzeme's" ideology to preserve the values of Latvian national art in an international environment, and second, the problem of generational change and the enrollment of young Latvian artists who continued to maintain "Dzintarzeme" values in exile.

The topicality of the research is determined by the fact that "Dzintarzeme" has not been studied so far. It is possible that, due to the closed type of the organisation and the small number of "Dzintarzeme" members in exile, the attempts of the corporation to preserve Latvian national art in exile have not received enough attention to this day. This research also provides an opportunity to supplement studies of Latvian national art in exile processes and advancement.

The chronological borders of this research are 1958, when the first exhibition in exile (in New York) revived the name of "Dzintarzeme", and 1987, which is the year of the sunset of "Dzintarzeme", when the active period ended and its existence turned into a chain of disagreements. Due to serious strifes among members, the Australian community ceased to exist and the American community became almost inactive.

\section{LATVIAN ART IN EXILE: FOCUS OF RESEARCH}

Latvian art in exile is widely discussed in publications of several art scientists, but more than fifty 


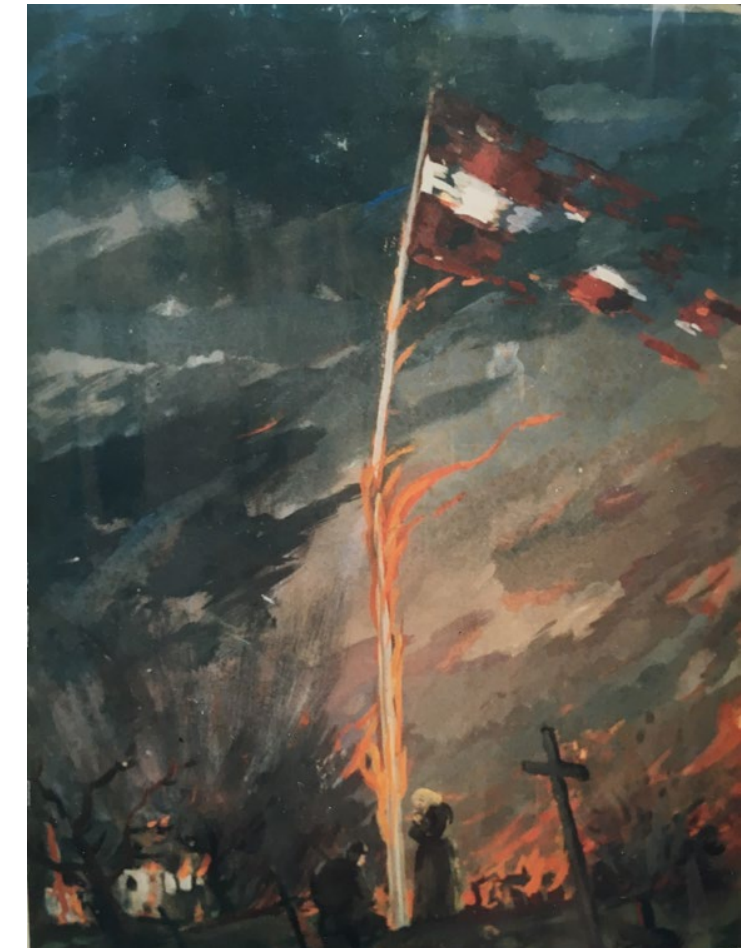

Fig. 3. "Dzintarzeme" member Jānis Cìrulis' painting "Dievs, dod mums ticību, ka kādreiz Latvijas karogs plìvos briva Latvijä" ("God, strengthen the belief that once again the flag of Latvia will fly again in free Latvia") from the series "Mana dzimtene kara liesmās" ("My homeland in war flames"). LNA LVA 2313, A.1, L.9

years of exile have not yet been fully covered and evaluated. In Soviet Latvia, there was an uncompromising position, propelled by the USSR propaganda, that no Latvian cultural life in exile should exist and therefore does not exist. The post-war art scientists and museum directors of Riga supposedly had to delete many names of the Latvian old masters who chose exile from the history of Latvian art, such as Jānis Kuga, Valdemārs Tone, Augusts Annus, Ludolfs Liberts, Bukards Dzenis, Sigismunds Vidbergs, Jānis Kalmite and others. It was only in the 1980s that these names returned to the lexicon of Riga art scientists and their works found places on the walls of Latvian museums.

Under the occupation, an objective study of the history of Latvian art was not possible, so the issues of interpretation of exile art came under the management of Latvian art scholars in exile. Various exhibition reviews in Latvian exile newspapers, such as Laiks, Latvija Amerikā, Austrālijas Latvietis, and others, exhibition catalogues, and other publications were dedicated to issues of exile art. The authors of these publications are old-generation Latvian art scholars, who received their education from the beginning of the 20th century to the Second World War and, due to political conditions, went into exile, and young Latvian art scholars who received their education in the new home countries. Art historian Andra Silapētere asserts that, being direct witnesses of the artistic process, they succeeded in developing a more extensive view in their observations of exile art, but it is important to clarify that, in most cases, these observations are documentary rather than analytical. ${ }^{11}$ They are mostly characterised by capturing the most vivid phenomena and events as well as attempts to identify the characteristics of exile art.

One of the first significant representatives of the old generation in texts about exile art is artist and art historian Janis Siliņš. Efforts to define the characteristics of Latvian exile painting can be seen in his publications. In 1964, he published a book Tèli un idejas (Images and ideas). ${ }^{12}$ It focuses on the development of Latvian art history and highlights the most visible trends in exile art. In 1983, one of the most qualitatively detailed reviews was published: "Glezniecība" (Painting) by Siliņš in Latvju enciklopēdija (The Latvian Encyclopedia), where he describes the processes of art life in exile from 1962 to $1982 .{ }^{13}$

Another important representative of the old generation is artist and art historian Juris Soikans. In 1983, he published his book Mākslas kritika un esejas (Art criticism and essays). It is a compilation of artists' and publicists' articles critically examining the trends of Latvian exile art. He focused on the issues of the preservation of Latvian national art in exile and the new Latvian artists' generation and its ability to express the identity of Latvian national art. ${ }^{14}$

A great turn in Latvian exile art was the journal Latvju Māksla (Latvian Art), published by artist and editor Arnold Sildeg from 1975. In the introduction to the first issue, the editorial office wrote: "Latvju māksla will be able to help drop the footbridge to art events, performances, and values created in the past, focusing on the works of artists and personalities who, due to their shyness or lack of material 
resources, have not been able or dared to build monuments for themselves while still alive." ${ }^{15}$ The content of the journal has always been exceptional in that it does not favour any one form of artistic expression or a group of artists but tends to embrace the processes of exile art as a whole. ${ }^{16}$ This is also confirmed by the thought expressed in the introduction: "To all the Latvian art lovers and friends who are not just sentimental homeland landscape buyers, the new collection of articles will help see a more complete picture. Who knows, maybe there is no new and old art? There is only good and worthless art, regardless of slogans and explanations." ${ }^{17}$

A similar development of thought is also observed in the articles of art historian and representative of the new exile art historian generation Eleonora Šturma. She has published in Latvian exile newspapers and in Latvju Māksla. She strives to look at exile art, independently of the artist generations, as a whole with different directions in expression. In 2011, 50 gadus mākslai pa pēdām (50 years in the footsteps of art), a compilation of her articles and publications in periodicals, was published. In Silapētere's opinion, Šturma does not seek to periodise art but rather suggests to interpret exile art as a single process which identifies the variation of the language of artistic expression. ${ }^{18} \mathrm{~A}$ similar author is exile art historian Nikolajs Bulmanis, who in 2010 published a book No vienas puses tā (loosely translated as On the One Hand), which summarises his articles from different time periods, published in exile periodicals. One of the topical essays is "Iss pārskats par latviešu mākslu emigrācijā” ("A brief overview of Latvian art in emigration"), which contains a significant characterisation of the development of Latvian diaspora art. ${ }^{19}$

In Latvia, a proper opportunity to focus on the issue of exile art appeared only after the restoration of independence in 1990, when the Iron Curtain was no longer an obstable to the contact between Latvia and the exile countries. The realisation that, for almost seventy years, parallel Latvian-made art was being created abroad, about which there was little information in Latvia, made historians consider the task of filling in the "white sheets". Although identification of the art heritage created by Latvians in exile became an object of interest for art specialists residing in Latvia, a fundamental art history work on Latvian exile art has not yet been written.

One of the first art historians who promoted exile artwork arrival to the present Latvian National Museum of Art in the 1980s was its director Ināra Nefedova. She focused on the issue of exile art very intensively, but her research activities are more characteristic of the exile heritage identification. She and her successor, current director of the museum Māra Lāce, have written on and talked about the collected heritage of Latvian exile art in the Latvian National Museum of Art in conferences and publications. Nefedova has also collected correspondence with the exile Latvian artists and art collectors and photos of Latvian art exhibitions abroad from 1970 to 1990 . She has gifted all the collected material to the State Archive of Latvia in the fonds No. 1638.

A significant turn in popularisation and research of exile art was the "Trimda, kultūra, nacionālā identitāte" ("Exile, culture, national identity") conference in Riga in 2004, organised by the World Federation of Free Latvians and the State Archive of Latvia. All papers presented in the conference were included in the collection of articles of the same name. ${ }^{20}$ The collection provides comprehensive information on cultural developments in exile, several interpretive sections about the social and cultural aspects of exile and factology essays on fine arts. For example: N̦efedova’s “Tēlotājas mākslas attīstības plusi un minnusi trimdā un Latvijā" ("The pros and cons of the development of fine arts in exile and in Latvia"), Dagnija Greste’s “Austrālijas latviešu kultūras dienu tēlotājas mākslas izstādes 1952-1992. Gadā” (“Australian Latvian Culture Days Exhibitions of Fine Arts 1952-1992”), Māra Lāce’s “Trimdas mākslas mantojums Valsts Mākslas muzejā” ("Exile Art Heritage at the National Museum of Art"), etc.

One of the most relevant attempts in recent years to highlight the direction of Latvian exile art and its features is the Latvian Art in Exile exhibition in 2013 at the "Arsenāls" Exhibition Hall of the National Museum of Art (curator Dace Lamberga). The first section of the exposition reflected on the beginning of the refugee era and the 1950s. The second 
part introduced diverse tendencies of realism, at the same time emphasising the quest for innovation. The third part was devoted to the late arrival of abstractionism in Latvian exile art. In total, about a hundred authors from Europe, the USA, and Australia were represented at the exhibition. Also in 2013, as a part of the exhibition, the Latviešu māksla trimdā (Latvian Art in Exile) catalogue was published by Dace Lamberga and Māra Lāce. ${ }^{21}$ The catalogue traces the diverse paths of art development in exile and the fates of the artists. The catalogue is especially valuable not only because of its quality reproductions but also because of the photographic material and the detailed chronology and bibliography of the most important events of exile art (1944-2013) presented in it.

In 2017, Silapētere described the problematics and reviewed the development of interpretation of Latvian art in exile in her article "Pārskats par latviešu trimdas mākslas līdzšinējām interpretācijām un to ievirzi" "“Overview of interpretations of Latvian art in exile and their essence"). The analysis of various texts demonstrates the viewpoint of overall processes in Latvian exile art and the basic trend of dividing artists into generations and taking art education as one of the most significant keys to each artist's individual signature style and the determination of shared trends. These factors are influence and reference to the development of artists' new creative output. These points are related to the manner of painting developed in Latvia, thus ascertaining the continuation of the styles formed in Latvia in exile, which, when developed further in the United States, follow a wide range of variations of realistic painting and individual attempts at abstract expressionism. ${ }^{22}$

\section{SOURCES}

To research the "Dzintarzeme" fraternity's life in exile, published and unpublished sources were used. The unpublished sources come exclusively from the State Archive of Latvia. The State Archive of Latvia preserves fundamental fonds about particular members of "Dzintarzeme". These fonds consist of documents gifted by "Dzintarzeme" members themselves or by their relatives after the restoration of Independence of the Republic of Latvia (1990), when, in 1992, the National Archives of Latvia became an independent institution free from Soviet governance. The most fundamental fonds that holds information about "Dzintarzeme" is the fonds of sculptor Verners Dukurs (LNA LVA F. 2061). This fonds consists not only of his private documents but also of correspondence between "Dzintarzeme" members, its protocols and circulars. Another important fonds is that of painter Jānis Cīrulis (LNA LVA F. 2131), which contains documents on his professional and artistic activities in preserving Latvian national art and connections with "Dzintarzeme". The third fundamental fonds is that of painter Arnold Sildeg (LNA LVVA F. 2652). It contains documents on his creative and social life as well as his work as the editor-in-chief of Latvju Māksla, correspondence, articles, photos, and materials about Latvian artists in exile, including the documents of "Dzintarzeme". Some information about certain "Dzintarzeme" members is available in fonds of other social workers or organisations in exile, for example, the fonds of "Latviešu studiju centra arhivs" (Archive of the Latvian Studies Center; LNA LVA F. 2123), where art scientist Jānis Silininš has collected information on and pictures of the paintings of the best-known Latvian artists in exile, including some "Dzintarzeme" members. Latvian exile research opportunities in the State Archive of Latvia are extensive, because one of the policies of the State Archive is to preserve cultural values created outside Latvia: the State Archive of Latvia has been promoting creation of fonds of Latvian social workers in exile since the 1990s.

Latvian periodicals of exile are a valuable material base of published sources. These periodicals hold important testimonies about the exile era in the history of Latvian culture. Painters Jānis Audriņš and Jānis Cīrulis, both members of "Dzintarzeme", constantly published articles in Latvian newspapers in the US, Canada, and Australia. Their articles were mostly about the history and life of "Dzintarzeme" as well as artistic achievements of individual "Dzintarzeme" members. The most popular newspapers were Laiks (in the US), Brìva Balss, later Latvija Amerikā (in Canada), and Austrālijas Latvietis (in 
Australia). Another important periodical which has included articles about "Dzintarzeme" members and their life and art is journal of Latvian fine art Latvju Māksla.

In historiography, information about "Dzintarzeme" is fragmentary. A comprehensive work on the history of Latvian student academic organisations Uzticigi draugam (Loyal to a friend) has been published by historian Valters Ščerbinskis. In it, Ščerbinskis mentioned all the student organisations that existed in interwar Latvia and in exile, including "Dzintarzeme", and made Uzticīgi draugam a fundamental guideline for future research of the lesser-known student organisations. ${ }^{23}$

Art historian Jānis Soikāns paid some attention to "Dzintarzeme's" activities in a few paragraphs of Mākslas kritika un esejas. He called "Dzintarzeme" the largest Latvian artist group in New York in the early $1950 \mathrm{~s} .{ }^{24}$ In art exhibition reviews compiled in 50 gadus mākslai pa pēdām, "Dzintarzeme" is also mentioned by Šturma, but mostly in a critical light, accusing "Dzintarzeme" exibitions of being too conservative in their art. For example: "In several decades, there has been no significant development in their translation of the soul to the painting, problem solving, or the technical plane." ${ }^{25}$

\section{RESTORATION OF “DZINTARZEME” AND PROMOTION OF NATIONAL ART}

Despite exile, members were able to rebuild and sustain the fraternity's life and gather its members. The main restorers of "Dzintarzeme" were painters Kārlis Šaumanis (1905-1971), Otto Grunde (19071982), Francis Ernests Bange (1895-1974), Jānis Audriņš (1898-1994), and Maksimilians Mitrevics (1901-1989). ${ }^{26}$ Audrinš was the main initiator of gathering the members and restoring the fraternity. Year 1958 brought first success: twenty-one members were found, who continued to belong to "Dzintarzeme" in exile. The second success was the first official "Dzintarzeme" exhibition in exile in honour of the 35th anniversary of the fraternity. ${ }^{27}$ The exhibition was opened in New York, in the French Art Centre gallery. This exhibition caught the attention of Soikāns. That year, Soikāns said that, out of all groups of Latvian artists in exile which organised group exhibitions, the "Dzintarzeme" New York community was the largest. In his opinion, this and next exhibitions were reminiscent of the national art colouring of interwar Latvia. ${ }^{28}$

In 1958, "Dzintarzeme" started a new page in its life. The fraternity's inner life changed its order because it had to adapt to the new circumstances.

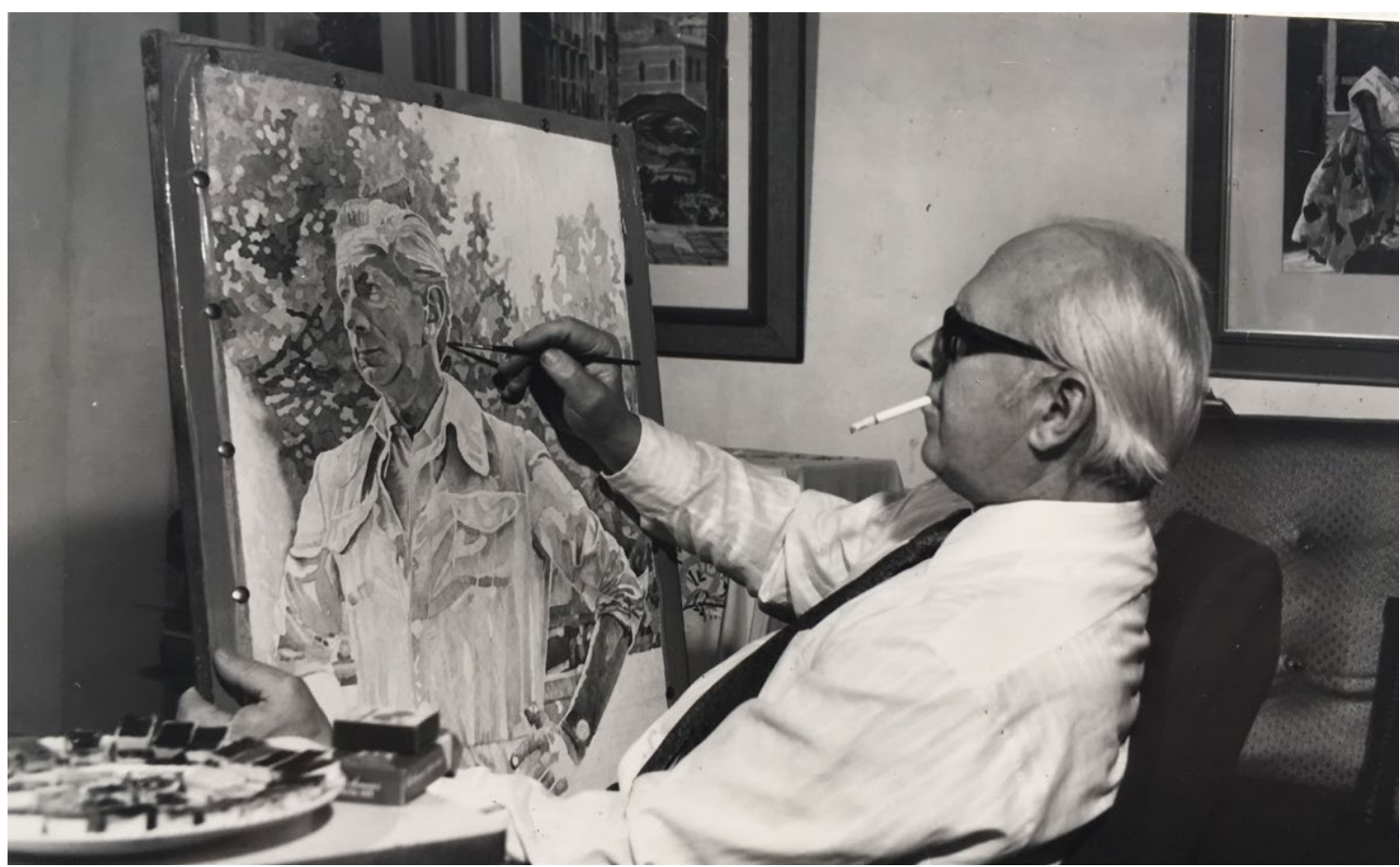


The scattering of its members was the main factor that instigated the changes. The fraternity lost most of its interwar traditions. First of all, instead of one community of "Dzintarzeme", now there were two-in New York and in Australia. The first Senior of the New York community was Šaumanis. ${ }^{29} \mathrm{He}$ was the Senior from 1958 to 1961 and from 1963 to 1966. The second Senior was Audrinsš: from 1961 to 1963, from 1966 to 1984, and from 1986 to 1990. In the period from 1984 to 1986, painter Eduards Dzenis was the Senior. The last one, till the end of the 90s, was Sildegs. The Australian community was founded three years later, in 1961. This community was led by a Consenior. The first Consenior, from 1961 to 1967, was Kārlis Veinbergs (Fig. 4). During this time the community was located in Sydney, but, when Dukurs was the second Consenior from 1967 to 1986 , it operated in Adelaide.

The second factor in all the changes were "Dzintarzeme's" main activities. They were mostly exhibitions: anniversary exhibitions and travelling exhibitions. The main audience of these exhibitions were exile Latvians. There were two main reasons of that: "Dzintarzeme's" ideology and the situation with exhibition halls. Most commercial exhibition halls in the
USA and Australia were too expensive, so "Dzintarzeme" used the opportunities to exhibit artworks in the houses of Latvian organisations, Latvian art studios, and churches. Concerning these exhibitions, the New York Senior Audriņš has said that the work of "Dzintarzeme" members is intended not only as a source of material income but also as a purely cultural performance for the Latvian people in exile, and that "Dzintarzeme" gives and shows the best it can: "The promise of our motto 'For beauty, a friend, and Amberland' will be fulfilled." All the scattered members of "Dzintarzeme", independently of daily work, according to their possibilities and abilities, preserved Latvian art traditions. Audriņš has emphasised several times in his articles that the members of "Dzintarzeme" were never into different innovations of art, neither during the interwar period nor in exile: "We have been accused of being old fashioned, of not following the spirit of the time. True, but all fashion is changing fast and the 'new' roads are removed so fast that often the artist can not return to previous values anymore." As an example, he often mentioned his study times: "Back then, there were many new modern theories and directions of art. Picasso's abstraction had not yet been silenced, expressionism was raging in Germany, but they failed to find

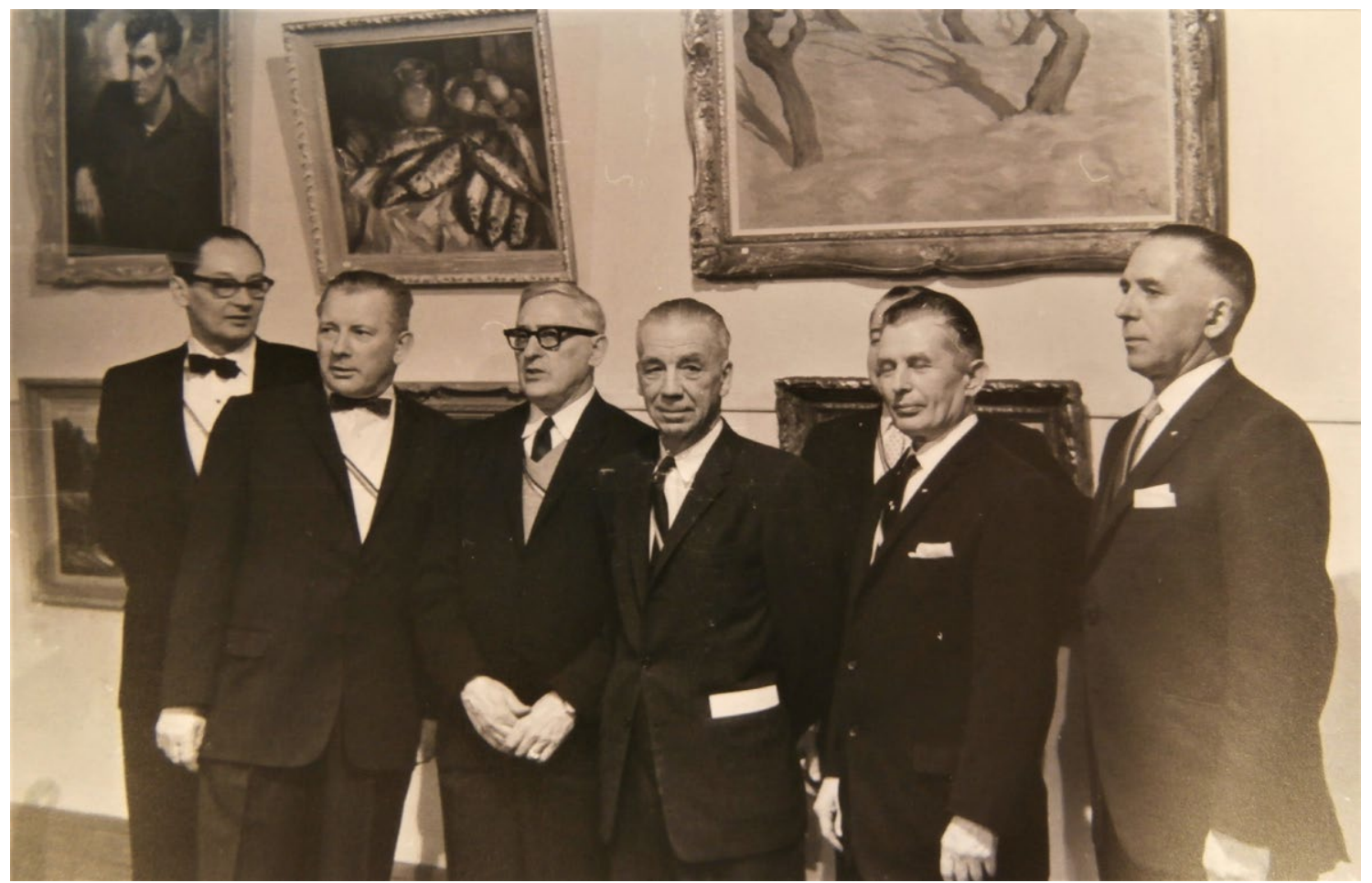

Fig. 5. One of the "Dzintarzeme" exhibitions in the USA, 1960s. LNA LVA 1996, A. F. 1v, L.100 
the students of the Latvian Academy of Art, most of whom were interested in national art." (Fig. 8). ${ }^{30}$

Anniversary and travelling exhibitions for "Dzintarzeme" members were the most succesful and effective way to preserve and popularise the Latvian national art traditions. From 1958 to 1973, "Dzintarzeme" organised 15 exhibitions in the USA, Canada, and Australia (Fig. 5). ${ }^{31}$ The exhibitions were held for lovers of Latvian art and also for the authors themselves, so that they could follow their own artistic growth. Although Latvians were the main and largest audience, there was also some interest from Americans, Canadians, and Australians, who would also buy some paintings. A great supporter of the organisation of exhibitions and "Dzintarzeme's" popularisation was the Exhibition Foundation, founded in 1960 by "Dzintarzeme" members. ${ }^{32}$ It was financed by voluntary donations and a 5 percent fee on each work sold at the exhibitions. The Foundation was used to cover the expenses of those members who participated in the exhibitions but were not able to pay for the transport or the exhibition participation fees. Money from this foundation was first used to transport the 45th anniversary exhibition paintings from Toronto to Boston and then to New York. In unexpected circumstances, it released expenses of the members who participated in exhibitions. ${ }^{33}$

From 1958 to 1960, three exhibitions were organised: two in New York and one in Boston. In 1961, "Dzintarzeme" held its first and only travelling exhibition in Australia, exhibiting its paintings in Melbourne and Sydney. Altogether, sixteen paintings were sold. From 1962 to 1964, there was only one exhibition: in 1963 in New York, in honour of “Dzintarzeme's" 40th anniversary (Fig. 6). 1965 was a fruitful year, when the Cleveland-Detroit-Chicago travelling exhibition was organised. A total of sixty paintings of "Dzintarzeme" members were exhibited, with some submitting as few as four and others up to twelve paintings, mostly landscapes, portraits, and still lifes. In the beginning, the route of the travelling exhibition was to be Detroit-Toronto-Chicago, but plans changed due to an incident when transporting the paintings. The paintings were supposed to be delivered from Detroit to Windsor (Canada), and from there sent to Toronto by rail, but the Windsor railway station's representative explained that they cannot guarantee the

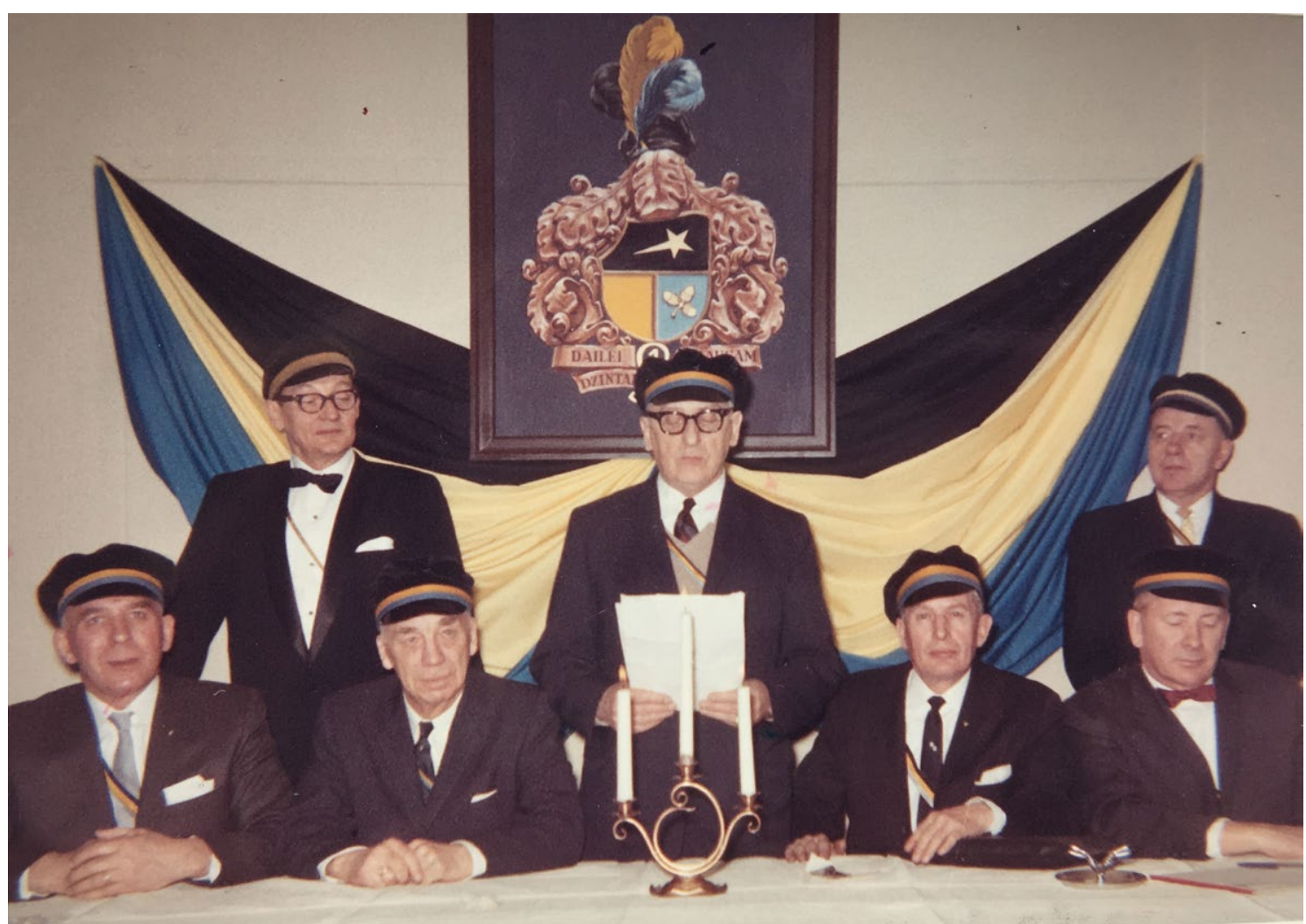

Fig. 6. Official meeting of the 40th anniversary of "Dzintarzeme", March 16, 1963. LNA LVA 2313, A.1, L.27 


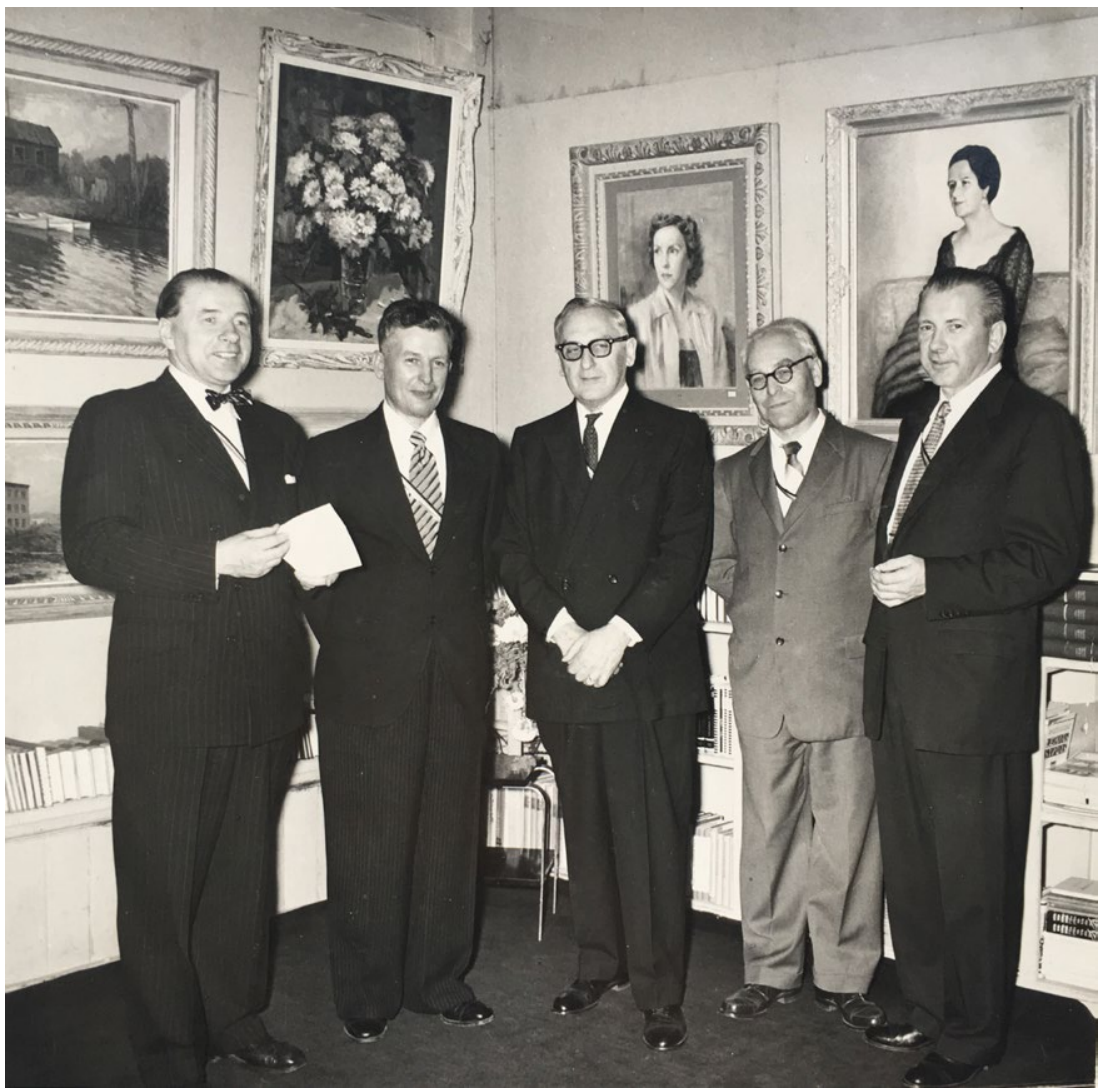

Fig. 7. "Dzintarzeme" exhibition in Boston. From left: Jānis Cīrulis, Kārlis Šaumanis, Jānis Audriņš, an unknown person, Otto Grunde; 1959 or 1967. LNA LVA 2313, A.1, L.27

delivery of the paintings on time. ${ }^{34}$ The members were able to change their plans quickly, choosing Cleveland as the first stop. In total, eighteen paintings were sold. In 1966, "Dzintarzeme" participated in exhibitions in Philadelphia and Washington, and in another travelling exhibition in 1967, this time Toronto-Boston (Fig. 7). In the end of the 1960s, there were only two exhibitions: the 45th anniversary exhibition in New York and the one in 1969 in Philadelphia. The 1960s are considered the most active period of "Dzintarzeme". In 1973, "Dzintarzeme" held its last exhibition: the 50th anniversary exhibition in New York. ${ }^{35}$ In 1976, "Dzintarzeme" members were looking forward to the 55th anniversary. Senior Audriņ̌ raised the question if the members would like to hold an exhibition in 1978, but it was not realised. The anniversary was commemorated only with the Presidium's greeting to all members of "Dzintarzeme". The Presidium, on behalf of Audriņš, sent out a circular: "While we are entering the second half of the century, let us keep in mind that it is not the number of members that is important, but their ideological position, quality of work, and trust in our motto 'For beauty, a friend, and Amberland"' ${ }^{36}$ The members would also receive congratulatory circulars for all the following anniversaries until the early 1990s.

\section{THE END OF “DZINTARZEME”}

The problem of generational change contributed to the slowly approaching end of existence. In the 1960s, there were some efforts to enroll young Latvian artists who could continue to maintain "Dzintarzeme" values in exile, but the number of "Dzintarzeme" members in exile plummeted. From 1958 to 1970, only three members joined "Dzintarzeme", all from the old generation of Latvian artists (in Australia): Oliegs Lapsa in 1960 and Laimonis Lauva and Jānis Audriṇš II in 1961. ${ }^{37}$ In 1958, there were twenty-one members in the fraternity, in 1961-twenty, in 1972-thirteen, in 1987-nine, and in 1994-only four members. The decrease in the numbers is explained by deaths of members and exclusions due to long-term debt of membership fees. 
It is clear that "Dzintarzeme" was too conservative and faithful to the old traditions to go looking for new members, and too picky when potential candidates showed up. In 1979, Audriņš sent a letter on this issue to Consenior of the Australian community Dukurs: "In all student corporations, the level has dropped-the behaviour of student corporation members is not correct. And at the same time, there is nothing to teach. And then the young artists are badly dressed. Shaggy hair and beards leave quite a frightening impression. This is the main reason why we stopped the admission. And there is no role played by their 'style' of art. To fight against the contemporary would only result in a quixotic defeat." ${ }^{38}$

Later on, the generational change was not the only problem. Because of their age, most members became inactive: anniversary exhibitions turned into exchanges of greeting cards or, sometimes, the communication stopped completely. In the 1980s, all living members were 69-90 years old. In 1986, the existence of "Dzintarzeme" reached a threshold because of serious disagreements between the US community Senior Audriņš and the Australian community Consenior Dukurs. As a result, on November 1, 1986, Audriņš and Dzenis expelled Dukurs for ninety-nine years and the Australian comunity stopped to exist. ${ }^{39}$ In 1987, the existence of "Dzintarzeme" turned into mutual disagreements, and Dukurs sent out circulars to all members with a suggestion to hold a new election of the Presidium, but Dukurs did not receive any responses. The expiration date of "Dzintarzeme" is not precisely identifiable. One possiblity is 1994, when former Senior Audriņš, shortly before his death, admitted in one of his letters that "Dzintarzeme" had finally ceased to exist. ${ }^{40}$ Dukurs arrived to Latvia in 1997. One of the purposes of his visit was to organise talks with the Art Academy of Latvia about restoring "Dzintarzeme" in Latvia, but conversation with the Academy ended without success. "Dzintarzeme" has not been restored to this day: although there has been some interest, the lack of live members and knowledge about "Dzintarzeme's" inner life has stoped the initiative of restoration.

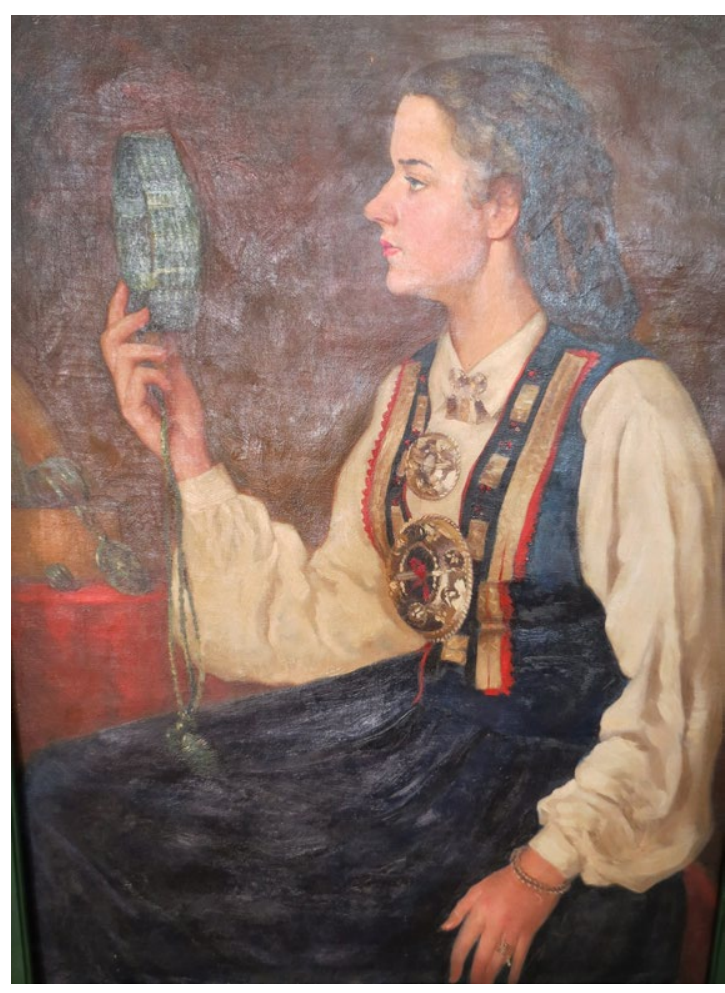

Fig. 8. Jānis Audriņšs painting “Tautumeita” (Folkgirl), 1960

\section{CONCLUSION}

Despite the international art enviroment, "Dzintarzeme" members were able to stay faithful to national art. The main "Dzintarzeme's" activity which played important role in the national art conservation policy was art exhibitions. Anniversary and travelling exhibitions continued to bring the name of Latvian national art into the world, mostly among the Latvian audience. Years from 1958 to 1973 can be confirmed as the most active phase in exile, when fifteen various exhibitions were held and exile Latvians, Americans, Canadians, and Australians had the opportunity to feel the spirit of Latvian national art. The period from 1973 to 1987 was the least active: the members aged, the distance between "Dzintarzeme" members became more cumbersome, during this least active period most of the members had their own solo exhibitions.

The most important problem was the generational change. In exile, only three new members were admitted, and only from the old generation of Latvian artists. Thus "Dzintarzeme" became a community that continued to unite only students of the Art Academy of Latvia or Latvian artists who represented 
the old generation. As a result of the members' aging and various misunderstandings, "Dzintarzeme" died in the 1990s together with its members, with no young Latvian artists who could continue to maintain "Dzintarzeme" values in exile. But there is also another aspect of the generational change that has preserved "Dzintarzeme" as an artist organisation that fully represents the old Latvian masters. This old Latvian artist generation with its interwar traditions of the Art Academy of Latvia undertook the responsibility and mission of preserving and representing their national cultural values in the multicultural USA and Australia. They had preserved their legacy: the European school and the peculiarities of national art. Most trends in modern art were unfamiliar and unattractive, even incomprehensible to them. Most artists, including "Dzintarzeme" members, painted landscapes of their lost homeland, and, among exile Latvian audiences, this realism and national romanticism obtained consent. The taste of the audiences was conservative, they strived after sentimentality. Although "Dzintarzeme" members did not concede to the new generation of Latvian artists and currents of art, they fulfilled their mission and were a meaningful part of the Latvian national art conservation policy in exile. This confirms the assumption that artist's generation and art education are one of the important keys in the development of expression in painting and the language of art. This is a significant aspect of the periodisation of Latvian exile art based on the change of generations.

\section{References}

Album Lettonorum 1870-1930. Riga: Valsts papīru spiestuve, 1930, 9.

Artist Jānis Cīrulis (1908-1995). The National Archives of Latvia, State Archive of Latvia. F. 2313.

Artist Verners Dukurs (dz. 1914). The National Archives of Latvia, State Archive of Latvia. F. 2061.

Audriņš, Jānis. “Dzintarzeme 1923.” Latvju Māksla, January $1,1979,530$.

Auls, E. "Kas ir studentu vienības?" Akadēmiskā Dzīve, 1960, 69-70.

Bulmanis, Nikolajs No vienas puses tā. Mansards, Rīga: Mansards, 2010, 318-334.

Cīrulis, Jānis. "12 mākslinieki un vinuu darbi." Laiks, April 8, 1958, 3.
Cīrulis, Jānis. “Jaunais atklājas." Laiks, November 9, 1960, 3.

"Dailei, darbam, Dzintarzemei." Latvija Amerikā, November 22, 1958, 5 .

“Dailei, draugam, Dzintarzemei." Laiks, March 14, 1973, 3.

"Dzintarzeme" art exhibitions (1959-1972). The National Archives of Latvia, State Archive of Latvia. F. 1996, A.1v, L. 100.

“Dzintarzemes jubilejas izstāde." Latvija Amerikā, March 30, 1966, 5.

“Dzintarzemes 35 gadi." Laiks, November 11, 1958, 3.

"Dzintarzemiešu ceḷojošā izstāde Toronto." Laiks, March 17, 1965, 3.

Fonds of "Dzintarzeme" 1923-1940. The National Archives of Latvia, Latvian State Historical Archive. F. 2477. “Garāmejot." Laiks, April 3, 1965, 7.

Kõpp, Johan. Eesti Üliópilaste Seltsi ajalugu 1870-1905. Tartu: Eesti Üliõpilaste Seltsi kirjastus, 1953, 13.

"Latvieši ārzemēs, zinātniskā asociācija." In Latvija un latvieši pasaulē. Rīga: Latvijas Enciklopēdija, 1993, 302.

Latviešu māksla (jaunie): Latviešu mākslinieku teorētiskie raksti un manifesti. Rīga: Neputns, 2002.

Latvijas kultūra (1920-1940). Rīga: Latvijas Mākslas muzeju apvienība, 1990, 6.

Latvijas Mākslas vēsture V 1915-1940. Riga: Latvijas Mākslas akadēmijas Mākslas vēstures institūts, 2016.

Niklāva Strunkes Trimdas grāmata. Stockholm: Daugava, 1971.

Photography collection of artist Artūrs Dronis. Cēsis History and Art Museum, CM100961-100966.

Silapētere, Andra. "Pārskats par latviešu trimdas mākslas līdzšinējām interpretācijām un to ievirzi." Latvijas Zinātñu akadēmijas Vēstis, part 71, 1, 2017, 91.

Sildegs, Arnolds. Artist and editor of journal Latvju Māksla (1915-2003). The National Archives of Latvia, State Archive of Latvia. F. 2652.

Sildegs, Arnolds. “Dzintarzemes 65 gadi." Latvju Māksla, January 1, 1988, 143.

Skuodis, Vytautas. Vilniaus Universiteto Filomatai ir Filaretai, 3, 4. http://www.šaltiniai.info/files/literatura/ LG00/Vytautas_Skuodis._Vilniaus_universiteto_ filomatai_ir_filaretai.LG4801Bpdf, 3-4, 7-8.

Soikans, Juris. Mākslas kritika un esejas. Toronto: Astras apgāds, 1983.

Ščerbinskis, Valters. Uzticīgi draugam: Latvijas studējošo slēgtās mūža organizācijas. Rìga: Prezidiju konvents, 2010.

Šturma Eleonora, 50 gadus mākslai pa pēdām. Rīga: Mansards, 2011, 58.

\section{Notes}

1 The oldest corporations still existing today were founded in the 18th century. These corporations belong to the tradition of student fraternities which wear colours (regalia) and practice academic fencing. German student corporations were traditionally recruited from nobility, royalty, and social elite, and are traditionally viewed as more aristrocratic than other German students and student societies.

2 Vilma Vaskelaite, "Karaliaučiaus universiteto studentų organizacijos 'Littuania' istorija ir veiklos bruožai," Bernardinai, November 23, 2018, http://www.bernardinai. 
lt/straipsnis/2018-11-23-karaliauciaus-universitetostudentu-organizacijos-littuania-istorija-ir-veiklosbruozai/172984

3,4 Vytautas Skuodis, Vilniaus Universiteto Filomatai ir Filaretai, http://www.šaltiniai.info/files/literatura/LG00/ Vytautas_Skuodis._Vilniaus_universiteto_filomatai_ir_ filaretai.LG4801B.pdf, 3-4, 7-8.

5 Johan Kõpp, Eesti Üliõpilaste Seltsi ajalugu 1870-1905, (Eesti Üliõpilaste Seltsi kirjastus, Tartu, 1953), 13.

6 Album Lettonorum 1870-1930 (Riga: Valsts papiru spiestuve, 1930), 9.

7 Protocols of the "Dzintarzeme" fraternity, LNA LVVA F. 2477 , A.1, L. 1,6

8 Statute of the "Dzintarzeme" fraternity, LNA LVA F. 2061, A.1v, L. 1, 2.

9 Regalia which is worn over the right shoulder to the left hip.

10 Latvijas Mākslas vēsture $V$ 1915-1940 (Latvijas Mākslas akadēmijas Mākslas vēstures institūts, Riga, 2016), 54, 259, 265.

11 Andra Silapētere, "Pārskats par latviešu trimdas mākslas līdzšinējām interpretācijām un to ievirzi," Latvijas Zinātnu akadēmijas Vēstis part 71(1) (2017): 91.

12 Jānis Siliňš, Tēli un idejas, (USA: Alfrēda kalnāja apgāds, 1964).

${ }^{13}$ Jānis Siliņš, "Glezniecība” in Latvju Enciklopēdija, 1.sēj. (ASV: Amerikas latviešu apvienības Latviešu institūts, 1983), 472-492.

14 Juris Soikans, Mākslas kritika un esejas (Astras apgāds Toronto, 1983), 58.

15 “Ievads," Latvju Māksla, May 1, 1975, 7.

16 Silapētere, 93.

17 "Ievads," 7.

18 Silapētere, 94.

19 Nikolajs Bulmanis, No vienas puses tā (Rīga: Mansards, 2010), 318-334.

20 Collection of conference articles Exile, culture, national identity, (Rīgas Latviešu biedrība, Pasaules Brīvo Latviešu apvienības kultūras fonds, Latvijas Valsts arhīvs, Riga, 2004).
21 Dace Lamberga, Latviešu māksla trimdā (Rīga: Neputns, 2013).

22 Silapētere, 102.

23 Valters Ščerbinskis, Uzticīgi draugam: Latvijas studējošo slēgtās mūža organizācijas, (Rīga: Prezidiju konvents, 2010), p. 168.

24 Soikans, 52.

25 Eleonora Šturma, 50 gadus mākslai pa pēdām (Rīga: Mansards, 2011), 58.

26 Karlis Veinbergs' letters to Verners Dukurs, LNA LVA F. 2061, A.1v, L. 12, 4.

27 "Dailei, darbam, Dzintarzemei," Latvija Amerikā, November 22, 1958, 5.

28 Soikans, 52.

29 The Senior is the head who is responsible for all affairs of a corporation in general, leading gatherings and events. A corporation is headed by a panel of three persons-senior, consenior, and secretary-who are elected by all active full members each semester.

30 “Dzintarzemes jubilejas izstāde," Latvija Amerikā, March 30, 1966, 5.

31 Jānis Audriņš, “Dzintarzeme 1923," Latvju Māksla, January 1, 1979, 530

32 Jānis Audriņšs letters to Verners Dukurs, LNA LVA F. 2061, A.1v, L. 6, 3.

33 "Dzintarzeme" protocols, circulars, letters, LNA LVA F. 2652 (the fund is not yet arranged and numbered.

34 "Garāmejot," Laiks, April 3, 1965, 7.

35 "Dzintarzeme" exhibition catalogues, invitations etc, LNA LVA F. 2061, A.1v, L. 3.

36 "Dzintarzeme" reports, LNA LVA F. 2061, A.1v, L. 2, 26.

37 "Dzintarzeme" reports, LNA LVA F. 2061, A.1v, L. 15, 10.

38 Jānis Audriņšs letters to Verners Dukurs, LNA LVA F. 2061, A.1v, L. 6, 12.

39 "Dzintarzeme" and Verners Dukurs' letters, LNA LVA F. 2061, A.1v, L. 9, 3.

40 "Dzintarzeme" and Verners Dukurs' letters, LNA LVA F. 2061, A.1v, L. 9, 10.

Agnija LESNIČENOKA

Latvijos meno akademija, Ryga, Latvija

Valstybinis Latvijos archyvas, Ryga, Latvija

\section{LATVIJOS DAILE்S AKADEMIJOS STUDENTŲ DRAUGIJA „DZINTARZEME“: NACIONALINIO LATVIJOS MENO IŠSAUGOJIMO STRATEGIJA IŠEIVIJOJE (1958-1987)}

Santrauka

Po Latvijos Respublikos paskelbimo 1918 metais Latvijos sostinė Ryga tapo jaunimo, siekiančio igyti išsilavinimą universitetuose, traukos centru. Kartu su studijomis studentai pradejo burti studentų bendruomenes ir kurti savo akademinị gyvenimą. 1923 m. Latvijos menos akademijos studentai įkūrè draugiją „Dzintarzeme“. Šio susibūrimo tikslas buvo suvienyti nacionaliai angažuotus Latvijos meno akademijos studentus, skatinti nacionalini Latvijos 
meną ir saviedukacijos vystymo procesą. Dauguma draugijos „Dzintarzeme“ narių buvo ištikimi seniesiems Latvijos meno meistrams ir Latvijos meno tradicijai. Kadangi „Dzintarzeme“ draugijos nariai iškilo kartu su Latvijos tapybos tradicijomis, kurios yra svarbus tarpukario Latvijos meno palikimas, šis susivienijimas buvo ir yra reikšmingas.

1940-aisiais Sovietų Sąungai okupavus Latvijos valstybę, „Dzintarzeme“ draugija buvo uždrausta. Dalis jos narių buvo deportuoti, dingo arba žuvo karo lauke, kiti pasirinko išeiviją. „Dzintarzeme“ nariai, apsigyvenę JAV, Kanadoje, Australijoje, sugebejo iš naujo atgaivinti ir palaikyti draugijos gyvenimą: suvienyti draugijos narius, organizuoti keliones ir metines meno parodas.

Taigi šiuo tyrimu ir straipsniu siekiama aptarti „Dzintarzeme“ draugijos veiklą išeivijoje (1958-1987) ir akcentuoti esminius nacionalinio Latvijos meno išsaugojimo strategijos faktorius. Pirmiausia „Dzintarzeme“ ideologijos potencialą išsaugoti nacionalines Latvijos meno vertybes tarptautinëje terpejje. Antra, išspręsti kartų kaitos problemą skatinant jaunų Latvijos menininkų, galinčių perduoti „Dzintarzeme“ draugijos vertybes išeivijoje, ịsitraukimą.

Reikšminiai žodžiai: studentų bendruomenès, draugija, „Dzintarzeme“, Latvijos meno akademija, išeivija, Latvijos nacionalinis menas.

\section{Agnija LESNIČENOKA,}

PhD student (or candidate), Art Academy of Latvia

State Archive of Latvia

E-mail: agnija.lesnicenoka@gmail.com 